\title{
Entrepreneurial Interest Determinants of Padangsidimpuan State Institute for Islamic Studies (IAIN) Students
}

\author{
Utari Evy Cahyani \\ Ekonomi Syariah, Fakultas Ekonomi dan Bisnis Islam, IAIN Padangsidimpuan \\ Email: utari@iain-padangsidimpuan.ac.id
}

\begin{abstract}
:
People assume that entrepreneurship is not a prestigious prefession to pursue. This results the entrepreneurial interest among students or college graduates is still low. This study aims to know the effect of personality, motivation, environment and education variables on the entrepreneurial interest of IAIN Padangsidimpuan students. Entrepreneurial interest variable is a categorical variable, they were the students who have an interest in entrepreneurship (1) and do not/don not have an interest in entrepreneurship (0). Data analysis methode used is logistic regression. The results of logistic regression analysis showed that variables influenced entrepreneurial interest of the students is education. According to the study results, the recommendation submitted to IAIN Padangsidimpuan is to improve the entrepreneurship education includes promoting the spirit of entrepreneurship through education in the classroom, field work, and seminars

[Masyarakat beranggapan bahwa wirausaha bukan merupakan profesi bergengsi untuk ditekuni menyebabkan minat berwirausaha di kalangan mahasiswa maupun lulusan perguruan tinggi masih rendah. Penelitian ini bertujuan untuk mengetahui pengaruh variabel kepribadian, motivasi, lingkungan dan pendidikan terhadap minat berwirausaha mahasiswa IAIN Padangsidimpuan. Variabel minat berwirausaha bersifat kategori yaitu mahasiswa yang memiliki minat berwirausaha (1) dan tidak/belum memiliki minat berwirausaha (0). Metode analisis data yang digunakan adalah regresi logistik. Hasil analisis regresi logistik diperoleh bahwa variabel yang mempengaruhi minat berwirausaha mahasiswa adalah pendidikan. Sesuai dengan hasil penelitian maka saran yang disampaikan kepada IAIN Padangsidimpuan adalah meningkatkan pendidikan kewirausahaan. Pendidikan kewirausahaan yang perlu ditingkatkan antara lain menumbuhkan jiwa wirausaha melalui, pendidikan di dalam kelas, praktikum di lapangan, dan seminar.]
\end{abstract}

Kata Kunci: Minat berwirausaha, kepribadian, motivasi, lingkungan, pendidikan. 


\section{INTRODUCTION}

Indonesia is a large country with a population of 237 million people in 2010 . The large population is one of the advantage if viewed from a large arket to sustain industrial development in the country and as a great power if the available human resources developed appropriately. On the other hand, a large population causes Indonesian Government faces a number of major social problems, they are: to provide education, food and clothing, job opportunities, and another problems.

The high rate of unemployment is an empirical phenomenon that occurs in Indonesia. Limited available job opportunities have increased the number of unemployed people. This condition will be further aggravated by the situation of global competition (e.g implementation of ASEAN Economic community) which will confront the college graduates of Indonesia to compete freely with the graduates from foreign countries. Therefore, they need to be directed and supported not only as job seeker-oriented, but also able and ready to become job creator.

Bringing up the spirit of entrepreneurship of university students is believed to be an alternative way to reduce the unemployment rate. Scholars are expected to become educated young entrepreneurs who are able to pioneer their own business which resuts in reduced the unemployment. Padangsidimpuan State Institute for Islamic Studies (IAIN) is one of institutions that carry out the higher education to result the scholars. There are four Faculties in IAIN Padangsidimpuan, they are Tarbiyah and Teaching Training Faculty, Sharia and Law Faculty, Da'wah and Communication Faculty, and Islamic Economy and Business Faculty. IAIN Padangsidimpuan obligates the students to take entrepreneurship as their study subject. Acitivities that support the growth of entrepreneurship spirit are also carried out such as entrepreneurship day and student day activity.

The increasing entrepreneurial activities both inside or outside the college have not been able to change the parents paradigm regarding the entrepreneurial profession. Parents still think that entrepreneurship is not a prestigious profession to pursue. This opinion is caused by the negative view among community about the entrepreneurial profession. Parents do not want their children to pursue this field and try to divert the children's attention to become civil servants, especially if their children have graduated from college. ${ }^{1}$ The lack of interest in entrepreneurship among college graduates is unfortunate. It should see the reality that existing employment will not be able to take all college graduates in Indonesia, so they start to choose entrepreneurship as their career choice.

There are two factors that influence the interest of entrepreneurship, they are internal and external factors. Internal factors come from the inside of entrepreneur, such as personal characters, attitudes, motivation, and individual ability that can give individual strength to entrepreneurship. External factors come from the outside of entrepreneur that can be the form of elements of surrounding environment such as family, physical environment, socioeconomic environment, and others.

Based on the description above, this study aims to find out the factors determine entrepreneurial interest of the students which is limited to inte rnal and external factors. With this study, it is expected that the institution will be able to promote the entrepreneurial interest of the students based on the factors that will be explained.

\footnotetext{
${ }^{1}$ Buchori Alma, Kewirausahaan untuk Mahasiswa dan Umum (Bandung: Alfabeta, 2011), 5. Iqtishadia: Jurnal Ekonomi dan Perbankan Syariah
} 
Utari Evy Cahyani

\section{Literature Review}

There are a few studies which focus on entrepreneurial interest. Suharti and Sirine (2011) investigate factors that influence entrepreneurial intentions of college students from 6 faculties at Satya Wacana Christian University. The results show a significant effect of the attitude factors, such as autonomy, authority, self realization, perceived confidence, and security, on the entrepreneurial intention of students. Likewise, this research also indicates the role of the contextual factors, such as academic support and social support in determining the entrepreneurial intentions of students. ${ }^{2}$

Other research by Ginting and Yuliawan (2015) has found that personal variable, social environment, demography and availablity of information, ownership of social network and the syncronous capital access has influenced the student's interest on running a private enterprise. Whereas the partial experiment had shown that personal variable, the availability of entrepreneurship information and the ownership of social network have influenced the entrepreneurship interest, whereas the environment variable, demography and the capital access are not influence towards the student interest on running a private enterprise by the students of STMIK Mikroskil Medan. ${ }^{3}$

Muljaningsih, et. al (2012) studied the entrepreneurial spirit among women farmers are affected by the training of organic processed food technology. Factors that affect the entrepreneurial interests of women farmer include labor, skills, land, and entrepreneurial spirit. Labor factor is measured by the indicator of famili member and the working ratio. Factor of skill is measured by indicators of organic crops knowledge, natural processed food, benefits of arrow root as a processed food, benefits of salacca as processed food, ease of producing the salacca processed food, and ease of producing arrowroot processed food. Factors of land have been measured with three indicators, namely drylands, salacca plant, and arrowroot plant. While entrepreneurship factors are measured by eight indicators of encouragement, integrity, accuracy, quietness, risk assessment, biophysical health, freedom, and human relations. Results show that entrepreneurial interest is influenced by the capital, labor, skill, land, and entrepreneurial spirit. Skill is the most dominant influence on entrepreneurial interests. 4

Research about the actual condition of the entrepreneurial student at the Faculty of Economics and Business, Gorontalo State University (FEB-UNG) by Morpanga (2014) identifying the determinant factor of student entrepreneurial intention and to formulate alternative ways to improve the entrepreneurial intention. Research concludes, first, it is generally, student entrepreneurial intention still relatively low, evidenced by the lack of FEB students become entrepreneur, low involvement in training/workshop and seminar about entrepreneurship inside or outside of campus as well as the lack of number of business plan that competed in Program of Student Creativity (PKM). Second, relatively low of entreprenurial intention is highly determined by the lack supporting of parents and family

\footnotetext{
2 Lieli Suhartini and Hani Sirine, Faktor-Faktor yang Berpengaruh Terhadap Niat Kewirausahaan (Entrepreneurial Intention) (Studi Terhadap Mahasiswa Universitas Kristen Satya Wacana, Salatiga), Jurnal Manajemen dan Kewirausahaan, Vol. 13, No. 2, September 2011, 124-134.

${ }^{3}$ Mbayak Ginting and Eko Yuliawan, Analisis Faktor-faktor yang Mempengaruhi Minat Berwirausaha Mahasiswa (Studi Kasus Pada Stmik Mikroskil Medan), Jurnal Wira Ekonomi Mikroskil, Vol. 5, No. 1, April 2015, 61-69.

${ }^{4}$ Sri Muljaningsih, et al., Faktor-faktor yang Mempengharuhi Minat Wirausaha Pengolahan Pangan Organik Pada Perempuan Tani Di Desa Wonokerto, Bantur, Malang, Wacana, Vol. 15, No. 2 (2012), 1218.

44

Iqtishadia: Jurnal Ekonomi dan Perbankan Syariah

Vol. 7 No.1 Juni 2020
} 
who works as civil servant or private employees, public perception and also entrepreneurial learning atmosphere and facilities that have to be acces inside of campus. Third, the solutions offered is multiplied the frequence of entrepreneurial practices, carried out of learning contextual periodically, provide the entrepreneurial facilities, business incubator program, business plan writing contest, budget allocation and entrepreneurial network integrated with local stakeholder. ${ }^{5}$

Aprilianty (2012) reveal the effect of potential entrepreneur personality, entrepreneurship knowledge, and environment on the entrepreneurial interest of vocational high school students. The results show that almost half of students have a low entrepreneurial interest. In other hand, personal entrepreneur personality gives a positive and significant effect on entrepreneurial interest. Entrepreneurial knowledge and family environment also has a significant positive effect on entrepreneurial interest. ${ }^{6}$

Haryani (2017) analyze the effect of entrepreneurial environment (government policies and procedures, socio-economic conditions, skill of entrepreneurial and business, financial assistance, and non-financial assistance) to the growth of entrepreneurship. Entrepreneurial environment conducive expected to bring new entrepreneurs and develop existing entrepreneurs. It can be concluded that the fators that affecting entrepreneurial growth in Sleman is socio-economic conditions, entrepreneurship and business skills, and financial assistance. ${ }^{7}$

Considering the existing literature, the hypothesis which we test in this study, can be articulated as follows:

Hypothesis 1: There is an influence between personality and entrepreneurial interest of student.

Hypothesis 2: There is an influence between motivation and entrepreneurial interest of student.

Hypothesis 3: There is an influence between environment and entrepreneurial interest of student.

Hypothesis 4: There is an influence between education and entrepreneurial interest of student.

\section{METHOD}

This study was conducted at IAIN Padangsidimpuan which is located at St. T. Rizal Nurdi KM 4.5 Sihitang, Padangsidimpuan. This study started from March to August 2018.

This was a quantitative study which used study design based on statistical procedure or by other way from quantification to measure the study variables. Quantitative study approach is study that is identical to the deductive approach, which start from general problems (theory) to specific things. ${ }^{8}$

\footnotetext{
5 Herwin Morpangga, Faktor Determinan Minat Wirausaha Mahasiswa Fakultas Ekonomi dan Bisnis Universitas Negeri Gorontalo, Trikonomika, Vol. 13, No. 1, Juni 2014, 78-90.

${ }^{6}$ Eka Aprilianty, The Effect of Potential Entrepreneur Personality, Entrepreneurship Knowledge, and Environment on Entrepreneurial Interest of Vocational High School Students, Jurnal Pendidikan Vokasi, Vol. 2, No. 3, November 2012, 311-324.

${ }^{7}$ Sri Haryani, Pengaruh Lingkungan Kewirausahaan Terhadap Pengembangan Wirausaha di Kabupaten Sleman, Ekuitas: Jurnal Ekonomi dan Keuangan, Vol. 1, No. 1, Maret 2017, 24-43.

${ }^{8}$ Asnawi dan Masyhuri, Metode Riset Pemasaran (Malang: UIN Maliki Press, 2011), 19.
}

Iqtishadia: Jurnal Ekonomi dan Perbankan Syariah

Vol. 7 No. 1 Juni 2020 
Number of study population was 5,577 students, which was the total active students in the study period. While the number of samples is determined using Slovin formula ${ }^{9}$ as follows:

$$
n=\frac{N}{\left(1+N e^{2}\right)}
$$

Where :

$$
\mathrm{n}=\text { total samples }
$$

$\mathrm{N}=$ total population

$\mathrm{E}=$ significancy level

Therefore, the sample size can be determined based on this calculation :

$$
\begin{aligned}
& n=\frac{5,577}{1+5,577\left(0.05^{2}\right)} \\
& n=373.23 \text { after integration become } 374 .
\end{aligned}
$$

This study used primary and secondary data. Primary data was obtained by filling out the questionnaire by respondents. Respondents in this study were determined using Slovin formula with $5 \%$ of alpha as many ass 374 students. While, secondary data was obtained from textbooks, journals, and data from government or private institution related to this study.

The study instrument (questionnaire) in this study will be tested using validity and reliability test. This steps was performed to make a good validity and reliability to the questionnaire distributed to respondents. There are two important terms that apply to a questionnaire, namely the necessity of a valid and reliable questionnaire.

This study used 5 variables : 1 dependent variable $(Y)$ namely entrepreneurial interest

\begin{tabular}{|c|c|c|c|c|}
\hline No. & Variable & Operational Definition & Indicator & Scale \\
\hline 1. & $\begin{array}{l}\text { Interest on } \\
\text { Entrepreneurship } \\
(\mathrm{Y})\end{array}$ & $\begin{array}{l}\text { The urge, interest, and the } \\
\text { willingness to work hard } \\
\text { to focus on doing the } \\
\text { entrepreneurship for a } \\
\text { living without having a } \\
\text { fear of upcoming risks, } \\
\text { the will to always learn } \\
\text { from the experience and } \\
\text { to expand the business }\end{array}$ & $\begin{array}{l}1=\text { The respondent } \\
\text { has the interest on } \\
\text { entrepreneurship } \\
2=\text { The respondent } \\
\text { has no interest on } \\
\text { entrepreneurship }\end{array}$ & Nominal \\
\hline 2. & Personality (X1) & $\begin{array}{l}\text { Individual characteristic } \\
\text { that impacts on the ability } \\
\text { to adapt with the } \\
\text { environment }\end{array}$ & $\begin{array}{ll}\text { - } & \text { Optimistic } \\
\text { - } & \text { Risk taker } \\
\text { - } & \text { Leader } \\
\text { - } & \text { Decision } \\
& \text { maker } \\
\end{array}$ & Interval \\
\hline 3. & Motivation (X2) & $\begin{array}{l}\text { An aspect to elaborate } \\
\text { one's attitude and }\end{array}$ & $\begin{array}{ll}\text { - } & \text { Interest } \\
\text { - } & \text { Urge } \\
\end{array}$ & Interval \\
\hline
\end{tabular}
and four independent variables (X) namely personality (X1), motivation (X2), environment (X3), and education (X4). The operational definition of variables in this study is as follows:

Table 1. Operational Definition of Variables

\footnotetext{
${ }^{9}$ Husein Umar, Metode Penelitian untuk Skripsi dan Tesis, Edisi Kedua (Jakarta: Rajawali Pers, 2013), 78. 
Entrepreneurial Interest Determinants of Padangsidimpuan State Institute for Islamic Studies (IAIN) Students

\begin{tabular}{|c|c|c|c|c|}
\hline & & $\begin{array}{l}\text { behavior in correlation to } \\
\text { the motivation inside }\end{array}$ & - Pride & \\
\hline 4. & Environment (X3) & $\begin{array}{l}\text { The nearest and main } \\
\text { environment }\end{array}$ & $\begin{array}{ll}\text { - } & \text { Father } \\
\text { - } & \text { Mother } \\
\text { - } & \text { Siblings } \\
\text { - } & \text { Relatives }\end{array}$ & Interval \\
\hline 5. & Education (X4) & $\begin{array}{l}\text { Education is a process } \\
\text { involving certain methods } \\
\text { in order to gain proper } \\
\text { knowledge, } \\
\text { comprehension, and } \\
\text { attitude }\end{array}$ & $\begin{array}{ll} & \text { Formal } \\
& \text { Education } \\
\text { - } & \text { Seminar } \\
\text { - } & \text { Training } \\
\text { - } & \text { Books }\end{array}$ & Interval \\
\hline
\end{tabular}

The data is analyzed by using logistic regression analysis. Meanwhile the process employs Microsoft Excel and SPSS ver 22. The researchers often create a model of research in which there is a correlation between $\mathrm{X}$ variable (predictor; independent) and $\mathrm{Y}$ variable (respond; dependent). Linier regression is often chosen to analyze the model, both the primal and dual ones. However, there are times when linier regression with OLS (Ordinary Least Square) method are not proper. The analysis using linier regression violates Gauss-Markov assumption. For instance, a case in which respond variable $(\mathrm{Y})$ has nominal-type data meanwhile its X Variable has interval or ratio type.

Basically, logistic regression is kind of similar to dual regression. The difference lies on the dependent variable which is 0 and 1 . Logistic regression can be distinguished into Binary Logistic Regression and Multinomial Logistic Regression. Binary Logistic Regression is used when there are only two possibilities in Y variable. As for Multinomial Logistic Regression, it is employed when there are more than two possibilities in $\mathrm{Y}$ as dependent variable.

Ghozali emphasizes that there are some steps to analyze using logistic regression, as mentioned below: 10

First step is assessing overall fit model towards data by doing some statistical examination. Hypothesis to assess model fit is:

$\mathrm{HO}$ : Model is fit to the data

$\mathrm{H} 1$ : Model is not fit to the data

This research uses statistic based on likelihood function. Likelihood L from the model is the probability that model in the hypothesis describes input data. To assess the zero hypothesis as well as the alternative, $\mathrm{L}$ is transformed into $-2 \mathrm{Log} \mathrm{L}$.

Cox and Snell's $R$ square is a coefficient that tries to copy $R$ square in multiple regression based on likelihood estimation with maximum value less than 1 , hence it is difficult to interpret. Nagelkerke's R square is a modification from the coefficient of Cox and Snell; it ensures the value varies among 0 to 1 by dividing Cox and Snell's R square with its maximum value.

From the Nagelkerke $\mathrm{R}^{2}$ it can be gained variability of dependent variable. The variability can be elaborated by variability of the independent ones. Hosmer and Lameshow's Goodness of Fit Test analyzes hypothesis zero that the empirical data is suitable with the model (there is no difference between model and data hence the model is fit).

${ }^{10}$ Imam Ghozali, Aplikasi Analisis Multivariate dengan Program SPSS (Semarang: Penerbit Universitas Diponegoro, 2002), 83.

Iqtishadia: Jurnal Ekonomi dan Perbankan Syariah 
If the value of Hosmer and Lameshow is 0.05 or less, the hypothesis zero is not valid. It means there is significant difference between model and the observation value so that the Goodness of Fit Test result of the model is not good as the observation value cannot be predicted. If the Hosmer and Lamshow test shows the value at 0.05 or more, the hypothesis zero can be claimed as valid.

In this subheading, the writer may describe the the context of discourse in detail. It may problematize the main concept discussing in the research writing. However, it is important to note, this subsection does not provide such theoretical framework. While at the same time, this subsection may provide method of gathering and analyzing data for which the data would be possible to conduct qualitative or quantitative approaches.

\section{RESULTS}

\section{Characteristic of the Respondents}

1. Gender

Based on the recapitulation of research instrument, the gender of the respondents is disclosed in Figure 1.

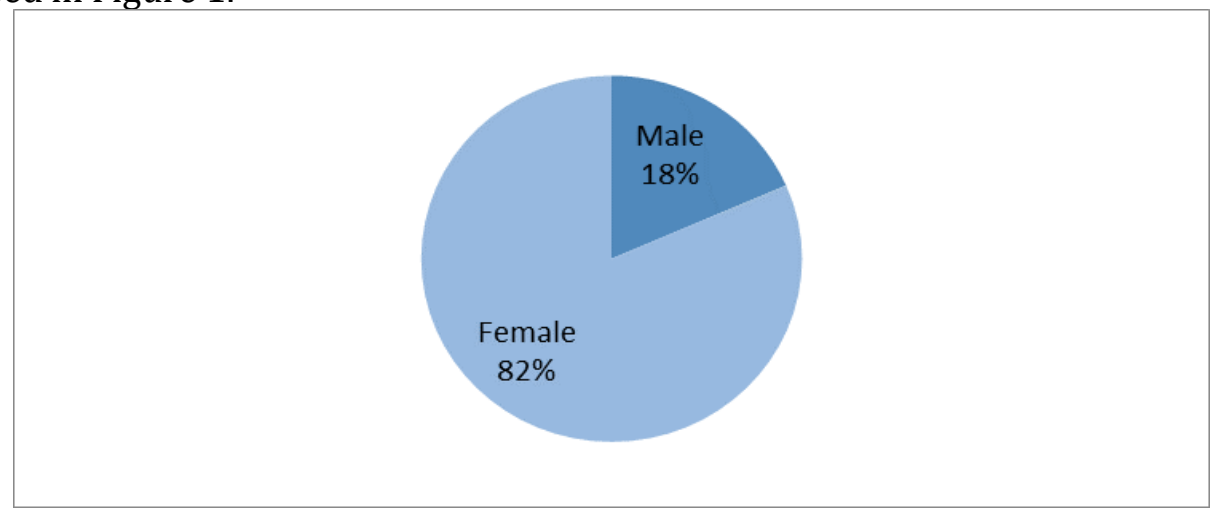

\section{Figure 1. Percentage of Respondents Based on Gender}

Figure 1 reveals that $82 \%$ of the respondents are females while the rest $18 \%$ are males.

\section{Faculties}

Based on recapitulation on research instrument, the faculties in which the respondents pursue their study are revealed in Figure 2. 


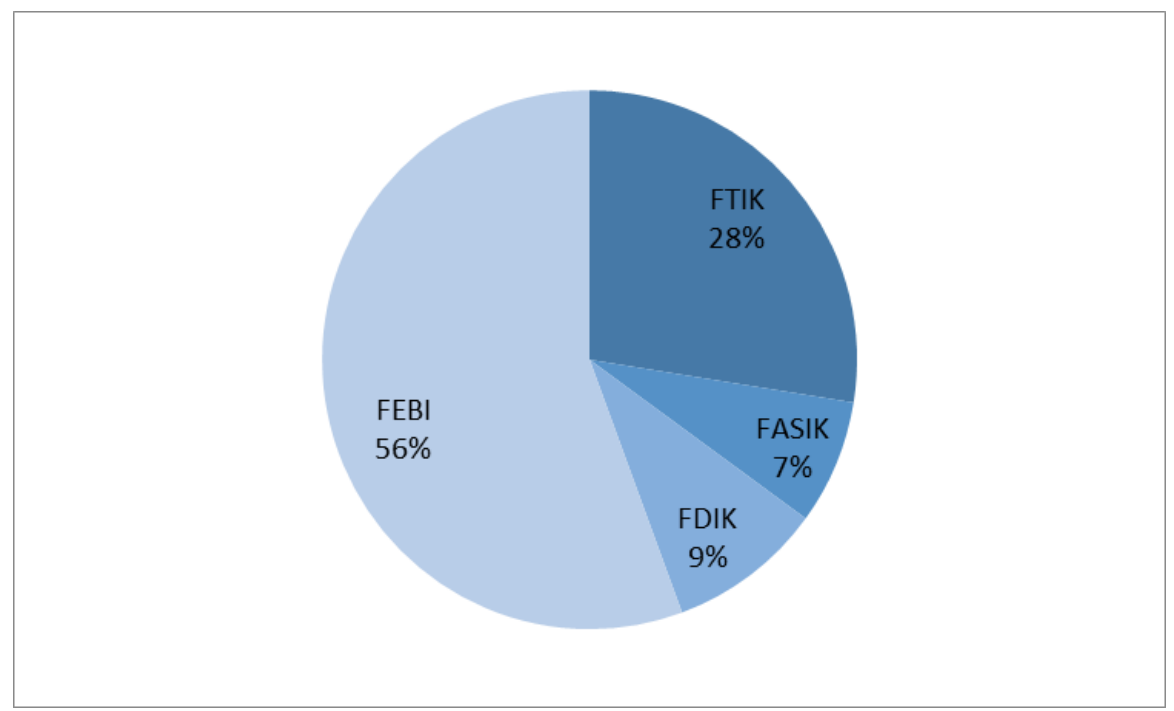

\section{Figure 2. Percentage of Respondents Based on the Faculties}

Figure 2 describes that the most respondents (56\%) comes from Fakultas Ekonomi dan Bisnis Islam (FEBI). The second place is crowned to Fakultas Tarbiyah dan Ilmu Keguruan whose students are among the 28\% of the whole respondents. Fakultas Dakwah dan Ilmu Komunikasi is placed third with their 9\% involvement while Fakultas Syariah dan Ilmu Hukum comes last with $7 \%$.

\section{Monthly Earning}

Based on recapitulation on research instrument, the respondents' monthly earning is presented by Figure 3.

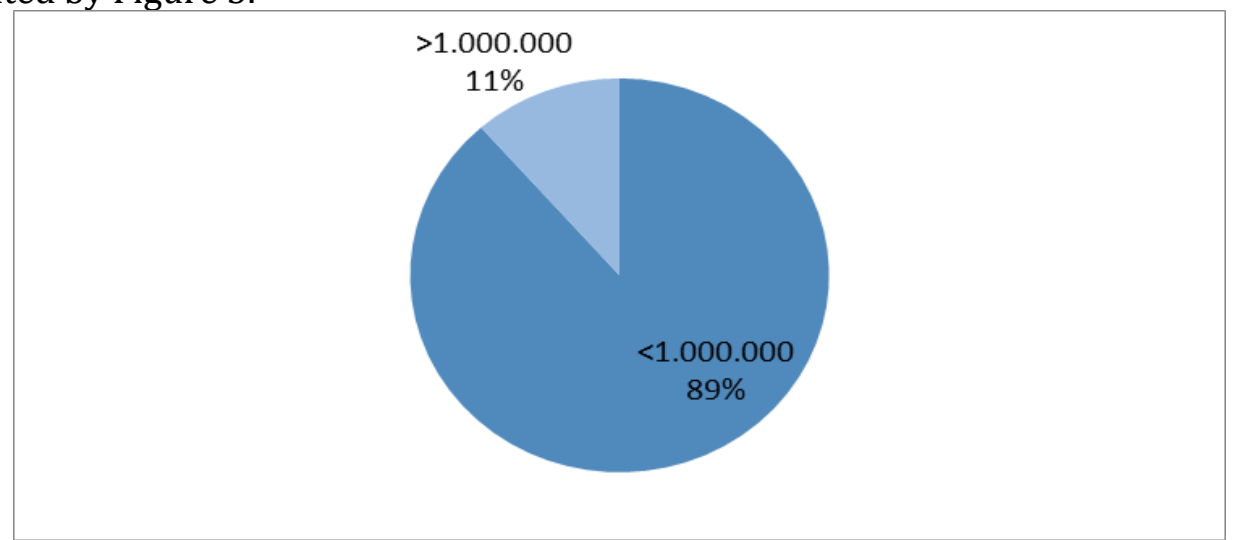

\section{Figure 3. Monthly Earning of the Respondents}

As described on Figure 3,11\% of the respondents earn more than IDR 1.000.000. As for the rest 89\% earn less than IDR 1.000.000.

\section{Monthly Expenditure}

Based on recapitulation on research instrument, the respondents' monthly expenditure is presented by Figure 4 . 


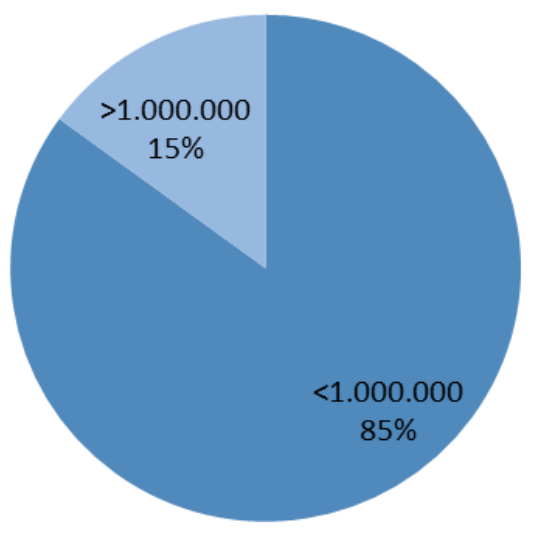

\section{Figure 4. Monthly Expenditure of the Respondents}

Based on figure 4 it can be concurred that $15 \%$ of the respondents spend more than IDR 1.000.000. The other $85 \%$ spend less than IDR 1.000.000.

\section{Validity and Reliability Test}

Validity Test

An instrument is valid when the correlation between factor score and total score is positive and has a value which is more than $0.03(\mathrm{r}>0.3)$ or $\mathrm{p}$-value $<0.05$. Table 2 presents the result of validity test on this research's instruments.

Table 2. Result of Validity Test

\begin{tabular}{|c|c|c|c|}
\hline Variable & Questions & p-Value & Explanation \\
\hline Interest on & Q1 & 0.000 & Valid \\
\hline Entrepreneurship (Y) & & & \\
\hline Personality (X2) & Q1 & 0.000 & Valid \\
& Q2 & 0.000 & Valid \\
& Q3 & 0.000 & Valid \\
& Q4 & 0.028 & Valid \\
& Q5 & 0.000 & Valid \\
& Q6 & 0.046 & Valid \\
& Q7 & 0.007 & Valid \\
& Q8 & 0.001 & Valid \\
& Q9 & 0.038 & Valid \\
& Q10 & 0.023 & Valid \\
& Q11 & 0.023 & Valid \\
\hline Motivation (X2) & Q1 & 0.003 & Valid \\
& Q2 & 0.003 & Valid \\
& Q3 & 0.010 & Valid \\
& Q4 & 0.003 & Valid \\
& Q5 & 0.025 & Valid \\
& Q6 & 0.001 & Valid \\
& Q7 & 0.000 & Valid \\
& Q8 & 0.000 & Valid \\
\hline
\end{tabular}


Entrepreneurial Interest Determinants of Padangsidimpuan State Institute for Islamic Studies (IAIN) Students

\begin{tabular}{|c|c|c|c|}
\hline & Q9 & 0.005 & Valid \\
\hline Environment (X3) & Q1 & 0.000 & Valid \\
& Q2 & 0.000 & Valid \\
& Q3 & 0.000 & Valid \\
& Q4 & 0.046 & Valid \\
& Q5 & 0.005 & Valid \\
& Q6 & 0.000 & Valid \\
& Q7 & 0.000 & Valid \\
& Q8 & 0.000 & Valid \\
& Q9 & 0.002 & Valid \\
\hline Education (X4) & Q1 & 0.000 & Valid \\
& Q2 & 0.000 & Valid \\
& Q3 & 0.000 & Valid \\
& Q4 & 0.000 & Valid \\
& Q5 & 0.000 & Valid \\
& Q6 & 0.000 & Valid \\
& Q7 & 0.000 & Valid \\
& Q8 & 0.007 & Valid \\
& Q9 & 0.000 & Valid \\
\hline
\end{tabular}

Table 1 reveals that the entire questions in each variable has p-value more than 0.05 . Hence it can be inferred that each question in this research instruments is valid.

\section{Reliability Test}

An instrument is reliable when the result of Alpha Cronbach is more than 0.6. The result of the test is presented in table 3 below:

Table 3. Result of Reliability Test

\begin{tabular}{|c|c|c|c|}
\hline No. & Variable & Cronbach's Alpha & Explanation \\
\hline 1 & $\mathrm{Y}$ & 1.000 & Reliable \\
\hline 2 & $\mathrm{X} 1$ & 0.709 & Reliable \\
\hline 3 & $\mathrm{X} 2$ & 0.734 & Reliable \\
\hline 4 & $\mathrm{X} 3$ & 0.771 & Reliable \\
\hline 5 & $\mathrm{X} 4$ & 0.765 & Reliable \\
\hline
\end{tabular}

As shown in the table, there is no Cronbach's Alpha coefficient that is less than 0.6. Therefore, it can be inferred that the entire instrument is reliable to be used in this research.

\section{Logistic Regression Test}

\section{Design of Empirical Model}

Model of Logistic Regression is needed to test the correlation between interest on entrepreneurship as dependent variable and four other elements as independent ones. Dependent variable is categorized as $Y=1$ for the respondents who have the interest and $Y=0$ for those who do not.

The characteristic of data used as independent variable is interval, which is described as follows:

$\mathrm{X} 1=$ Personality 
Utari Evy Cahyani

$\mathrm{X} 2=$ Motivation

$\mathrm{X} 3=$ Environment

$\mathrm{X} 4=$ Education

$\operatorname{Ln} \frac{\pi_{i}}{1-\pi_{i}}=\alpha+\beta 1 \mathrm{X} 1+\beta 2 \mathrm{X} 2+\beta 3 \mathrm{X} 3+\beta 4 \mathrm{X} 4+\varepsilon$

2. Goodness of Fit test

The result of the test is described in Table 4

Tabel 4. Goodness of Fit Test

Hosmer and Lemeshow Test

\begin{tabular}{|l|l|l|l|}
\hline Step & Chi-square & df & Sig. \\
\hline 1 & 9.459 & 8 & 0.305 \\
\hline
\end{tabular}

The Hosmer-Lemeshow test is employed with hypothesis as mentioned below:

$\mathrm{HO}=$ Model fits the data (model is able to elaborate data)

H1 = Model does not fit the data

The criteria of the test is the validity of $\mathrm{H} 0$ is accepted if the p-value on the distributed chi-square reaches 0.05 or more. As shown on the table 4 the result of p-value is 0.305 , which is more than 0.05 . Therefore, the validity of $\mathrm{HO}$ is accepted. In other words, there is no significant difference between the observation result and the possible result of prediction on model.

Tabel 5. Coefficient of Determination

Model Summary

\begin{tabular}{|l|l|l|l|}
\hline Step & -2 Log likelihood & $\begin{array}{l}\text { Cox \& Snell R } \\
\text { Square }\end{array}$ & $\begin{array}{l}\text { Nagelkerke R } \\
\text { Square }\end{array}$ \\
\hline 1 & $337.496^{\mathrm{a}}$ & 0.045 & 0.073 \\
\hline
\end{tabular}

Estimation terminated at iteration number 5 because parameter estimates changed by less than .001 .

Table 5 discloses the coefficient of determination as the result of logistic regression, which is 0.073 , and it can be concluded that $7.3 \%$ of dependent variable can be presented by logistic regression model.

Classification Model is used to show the quality of the prediction result on the model. A good model has high level of accuracy. Table 6 below reveals the result of model accuracy assessment.

Table 6. Model Accuracy Assessment Classification Table

\begin{tabular}{|l|l|l|l|l|}
\hline \multicolumn{2}{|l|}{ Observed } & \multicolumn{2}{l|}{ Predicted } & Percentage \\
& & Y & \\
\hline & & $\begin{array}{l}\text { Has the } \\
\text { interest }\end{array}$ & $\begin{array}{l}\text { Has no } \\
\text { interest }\end{array}$ & \\
\hline Step 1 & & 67 & 1.5 \\
Y & $\begin{array}{l}\text { Has no interest } \\
\text { Has interest }\end{array}$ & 1 & 303 & 99.0 \\
Overall Percentage & 3 & 31.3 \\
\hline
\end{tabular}

a The cut value is .500 
According to the table, the accuracy of prediction is $81.3 \%$. From the table, out of 68 students who do not have entrepreneurial interest is predicted that 67 students will have an entrepreneurial interest. Whereas, among 306 students who have an entrepreneurial interest, 303 students are predicted correctly by the model and 3 students are not predicted correctly by the mdoel.

\section{Partial Significant Level Test}

To test the significant level partially this research employs Wald statistic value in order to figure out whether independent variable affect model in partially-significant manner. If the value of sig. Wald statistic is less than 0.5 then the independent variables can be inferred to have partial-significant impact on dependent variable. The result of the test is presented in Table 7 below.

Tabel 7. Significant Level Test

\begin{tabular}{|l|l|l|l|l|l|l|l|l|l|}
\hline \multicolumn{2}{|l|}{} & B & S.E. & Wald & df & Sig. & Exp(B) & \multicolumn{2}{|c|}{$\begin{array}{l}\text { 95\% C.I. for } \\
\text { EXP (B) }\end{array}$} \\
\cline { 5 - 10 } & & & & & & & Lower & Upper \\
\hline $\begin{array}{l}\text { Step } \\
1 \mathrm{a}\end{array}$ & $\mathrm{X} 1$ & .039 & .049 & .619 & 1 & .431 & 1.040 & .944 & 1.145 \\
\hline & $\mathrm{X} 2$ & -.022 & .042 & .275 & 1 & .600 & .978 & .901 & 1.062 \\
\hline & $\mathrm{X} 3$ & .074 & .039 & 3.702 & 1 & .054 & 1.077 & .999 & 1.162 \\
\hline & $\mathrm{X} 4$ & .081 & .032 & 6.652 & 1 & .010 & 1.085 & 1.020 & 1.154 \\
\hline & Constant & -4.957 & 2.035 & 5.931 & 1 & .015 & .007 & & \\
\hline
\end{tabular}

a Variable (s) entered on step 1: X1, X2, X3, X4

Based on the test in partial manner, it is revealed that X4 is the only significant one considering its Sig value at 0.01 . On the other sides X1, X2, X3 have Sig value as much as $0.431,0.600,0.054$ respectively. The three value mentioned prior are higher than 0.05 ; hence the conclusion is $\mathrm{X} 1, \mathrm{X} 2$, and $\mathrm{X} 3$ have no partially-significant impact on $\mathrm{Y}$.

\section{Model Simultaneous Test}

The simultaneous test is carried out by using compounding correlation to Chi-Square. If the value of Sig. is less than 0.05 then the entire independent variables affect dependent variable simultaneously. The result of the test can be seen in Table 8 .

Table 8. Model Simultaneous Test Omnibus Test of Model Coefficients

\begin{tabular}{|l|l|l|l|}
\hline Step 1 & Chi-square & df & Sig. \\
\hline Step & 17.161 & 4 & 0.002 \\
Block & 17.161 & 4 & 0.002 \\
Model & 17.161 & 4 & 0.002 \\
\hline
\end{tabular}

Compounding correlation of $\mathrm{X} 1, \mathrm{X} 2, \mathrm{X} 3$, and $\mathrm{X} 4$ towards $\mathrm{Y}$ is tested by Chi-Square method. The result reveals the value of Chi-Square as much as 17.161 and the value of Sig at 0.002 . The value of sig is higher than 0.05 hence the independent variables containing Personality (X1), Motivation (X2), Environment (X3), and Education (X4) is correlated to Interest on Entrepreneurship (Y). 
Utari Evy Cahyani

\section{Interpretation of Coefficient}

Mathematical Equation arranged based on the tests are as follows:

$\operatorname{Ln} \frac{\pi_{i}}{1-\pi_{i}}=-4,957+0,039$ Personality $-0,022$ Motivation $+0,074$ Environment $+0,081$

Education $+\varepsilon$

Based on test of significance, Education is the only variable that significantly affect the dependent variable. Value of $\exp (\mathrm{B})$ of Education is 1.085; in other words, if Education is improved as much as 1 entity then the frequency of students who have interest on entrepreneurship will increase 1.085 times.

\section{CONCLUSION}

Based on logistic regression analysis, Education is the only independent variable that has significant effect towards the students of IAIN Padangsidimpuan interest on entrepreneurship. Personality, motivation, and environment have no impact on the dependent variable. However, test of simultaneous effect shows that the entire independent variables affect students of IAIN Padangsidimpuan's interest on entrepreneurship.

Taking the result into consideration, the author suggests IAIN Padangsidimpuan to improve the education on Entrepreneurship. Students need to be educated more in growing the passion in entrepreneurship through classes, direct practice, and seminar.

\section{Refferences}

Asnawi dan Masyhuri, Metode Riset Pemasaran. Malang: UIN Maliki Press, 2011.

Buchori Alma, Kewirausahaan untuk Mahasiswa dan Umum. Bandung: Alfabeta, 2011.

Eka Aprilianty, The Effect of Potential Entrepreneur Personality, Entrepreneurship Knowledge, and Environment on Entrepreneurial Interest of Vocational High School Students, Jurnal Pendidikan Vokasi, Vol. 2, No. 3, November 2012, 311-324.

Herwin Morpangga, Faktor Determinan Minat Wirausaha Mahasiswa Fakultas Ekonomi dan Bisnis Universitas Negeri Gorontalo, Trikonomika, Vol. 13, No. 1, Juni 2014, 78-90.

Husein Umar, Metode Penelitian untuk Skripsi dan Tesis, Edisi Kedua. Jakarta: Rajawali Pers, 2013.

Imam Ghozali, Aplikasi Analisis Multivariate dengan Program SPSS. Semarang: Penerbit Universitas Diponegoro, 2002.

Lieli Suhartini and Hani Sirine, Faktor-Faktor yang Berpengaruh Terhadap Niat Kewirausahaan (Entrepreneurial Intention) (Studi Terhadap Mahasiswa Universitas Kristen Satya Wacana, Salatiga), Jurnal Manajemen dan Kewirausahaan, Vol. 13, No. 2, September 2011, 124-134.

Mbayak Ginting and Eko Yuliawan, Analisis Faktor-faktor yang Mempengaruhi Minat Berwirausaha Mahasiswa (Studi Kasus Pada Stmik Mikroskil Medan), Jurnal Wira Ekonomi Mikroskil, Vol. 5, No. 1, April 2015, 61-69.

Sri Haryani, Pengaruh Lingkungan Kewirausahaan Terhadap Pengembangan Wirausaha di Kabupaten Sleman, Ekuitas: Jurnal Ekonomi dan Keuangan, Vol. 1, No. 1, Maret 2017, 24-43.

Sri Muljaningsih, et al., Faktor-faktor yang Mempengharuhi Minat Wirausaha Pengolahan Pangan Organik Pada Perempuan Tani Di Desa Wonokerto, Bantur, Malang, Wacana, Vol. 15, No. 2 (2012), 12-18. 